\title{
PROMISES TO MARRY MADE WITHIN A PROSCRIBED \\ PERIOD (BUT NOT TO BE CONSUMMATED UNTIL THE END OF THAT PERIOD)
}

By Nigk Galifianakis*

Many jurisdictions have enacted statutes imposing restrictions on the right to marry after divorce. ${ }^{1}$ These restrictions, it appears, have been designed to punish the guilty party or to provide a cooling period for possible reconciliation between parties, and also to maintain public morality by requiring a certain period to elapse before either party can remarry. Some of the statutes have been interpreted to mean that marriages within the prohibited period are voidable only and not void, but the majority rule is that marriages violating the provisions of the statute are absolutcly void. ${ }^{2}$

This being the view of marriages entered into in violation of a state statute, the question arises: How should the courts treat a promise to marry entered into within the proseribed period, when the marriage itself is not to be consummated until after the restricted period has terminated? Should the courts, favoring the equities of the plaintiff, enforce such a promise and thereby permit recovery for breach of the marriage contract; or should the courts, favoring the initial marriage, hold such a promise unenforecable on the grounds that the same policy which declares a marriage within the prescribed period void applies with equal force to a contract to marry notwithstanding the fact that the second marriage is to be performed after the statutory period of prohibition?

One solution to the problem is manifested in the recent Texas decision of Nicholas $v$. Holder, ${ }^{3}$ involving an action for breach of promise to marry. The court held that since the alleged marriage promise had been made within one year of the promisor's divoree on the grounds of cruel treatment, it was against public policy irrespective of the date set for the proposed marriage and therefore unenforceable. The statute involved in the case provided:

"Neither party to a divoree suit, where a divorce is granted upon the ground of eruel treatment, shall marry any other

* 3rd year law student, Duke University; A.B. Duke, 1951.

12 Vernier, AMrerican FanituY LaW (1932 ed. ), \$\$ 88, 92, and 127.

- See Madden, Persons and DoMrestic Relations (1931 ed.), p. 42.

s 244 S.W.2d 313 (Tex. Civ. App. 1951). 
person for a period of twelve months next after such divorce is granted, but the parties so divorced may marry each other at any time." 4

The court explained that when the divorce was granted on grounds other than cruelty, the statute did not apply. The court found that the purpose of the statute was to encourage the remarriage of persons who had been divorced on the grounds of cruelty, rather than to punish the parties involved. It was held that an agreement to marry militated against the public policy of the statute, notwithstanding the fact that the statute did not expressly mention contracts to marry. This conclusion was reached by the court's elasticizing the words of the statute, to wit, "neither party shall marry," to include that neither party shall be capable of contracting to marry. In reaching this conclusion the court cited a leading Oregon case involving a statute which expressly prohibited a contract to re-marry within the period of prohibition. ${ }^{5}$

The decision in the Holder case seems to be fair under the facts there presented, but the court's analysis of the problem is not very realistic. The court maintains that such an agreement, even though not to be consummated until the end of the prohibited period, is unenforceable, stating in general terms that it is against public policy. A more cogent reason for the court's decision was the fact that the plaintiff in the Holder case not only had been married four times, but had associated with the defendant when she knew that he was still married and was herself divorced after she had met the defendant. These facts were undoubtedly persuasive in the court's final decision, but the court does not consider the plaintiff's knowledge as a factor in the case. Suppose that the plaintiff did not know that the defendant was incompetent to marry due to the statutory bar, or that defendant concealed the fact and promised to marry the plaintiff at a time when the prohibition had expired. Would the statute under these circumstances be construed to mean that neither party shall be capable of entering into a contract? Or is this a situation where a suit for breach of promise should lie?

Another recent Texas case $^{6}$ dealing with the same statute ${ }^{7}$ should be contrasted with the Holder case. The court in holding

-Vernon's Texas Civ. Stat. ANn. (1951), AzT. 4640.

- Vnuk v. Patterson, 118 Ore. 602, 247 Pac. 766, 47 A.I.R. 394 (1926).

- Gress v. Gress, 209 S.W. 2 1003 (Tex. Civ. App. 1948).

' Supra, note 4. 
a marriage consummated in violation of the statute to be valid cited 28 Tex. Jur. 731 as follows:

"Even though the divorce statute declares that neither party to a deeree granted upon the grounds of cruel treatment shall marry any other person for a period of twelve months next after the divorce is granted, a marriage contracted within such period is not void. The decree is final and not interlocutory."

The court held that the appellant was estopped to have the voidable contract, which he entered into with the knowledge that it was in violation of the statute, rescinded, and decided that the lower court did not err in refusing to annul the marriage. The court added that appellee's inability to marry would not render the marriage a nullity, since the legislature had not seen fit to make marriages in violation of the statute void. In the light of the two decisions, the present status of the statute seems confusing: A marriage consummated within the statutory period is permissible even though prohibited, but a promise to marry after the proscribed period is not enforceable. Admittedly, a situation where the marriage has been consummated can easily be distinguished from the case where there is only a contract to marry. In the former situation public policy favors the continued existence of marriage, even though the marriage was consummated during the statutory period of prohibition. Similarly, in the latter situation, it would seem that policy should favor the enforcement of a contract to marry in certain circumstances. ${ }^{8}$ At least it is suggested that the court should have diseretion to determine whether such marriage contracts are void or voidable.

Another case to be contrasted with the Holder case is Kungling v. Williamson, ${ }^{9}$ which involved an action for breach of promise to marry. The defendant had made a promise to marry two days before the expiration of the six-month proscribed period following her divorce, but the marriage was not to be consummated until after the expiration of the period. The statute in this case provided: "No marriage shall be contracted ... within six months after either [party] has been divorced from a former spouse."10 Notice should be given to the fact that here the statute employed the word "contracted," whereas in the Holder case the court extended the pur-

- VerRIER, op. cit. supra note 1 , Vol. 1, \$6.

- 231 Minn. 135, 42 N.W.2d 534 (1950).

Io Minn. Stat. ANN. (1945), \& 517.03. 
view of the Texas statute to include a promise to marry. In the Kungling case the court construed the statute to prohibit the consummation of marriage only, leaving a promise to marry valid even though it was made within the proscribed period. In the words of the opinion:

"What is prohibited by the above statute?" Does it prohibit a promise of marriage within the six month period or only the act of marriage itself? It is elementary that statutory words and phrases are to be construed according to the rules of grammar and according to their common and approved usage unless to do so would be inconsistent with the intent of the legislature. 'Contracted' as used in the statute is a transitive verb. Webster's International Dictionary ${ }^{12}$ points out that to contract marriage or matrimony is to enter into marriage."

The court ${ }^{13}$ then stated that the statute did not prohibit a contract for marriage and allowed the plaintiff to recover.

From the cases it can readily be seen that there is a difference of opinion as to the proper rule to be applied to a marriage promise made by a divorced person during the statutory period of prohibition. One line of authority maintains that such a promise is valid if the marriage is not to take place until the termination of the period. ${ }^{14}$ Another view holds that such a promise is invalid even though the marriage itself is not to be consummated until after the proscribed period has elapsed.15

What are the circumstances which warrant enforceability of a promise to marry made during the prohibition period? Knowledge on the part of the promisee of the promisor's competency has played an important role in the decision of some of the cases $;^{16}$ for example, where the promisee is ignorant of the promisor's incompetency to marry due to statutory probibition or divorce decree. In spite of the public policy to hold promises by married persons unenforce-

22 Tbid.

12 2d Ed., 1947, p. 578.

${ }^{13}$ Kungling v. Williamson, 231 Minn. 135, 42 N.W.2d 534 (1950).

14 Ibid. See also, Gress v. Gress, supra note 6; Leininger Lumber Co. v. Dewey, 86 Neb. 659,126 N.W. 87 (1910).

${ }^{25}$ Nicholas v. Holder, 244 S.W.2d 313 (Tex. Civ. App. 1951); Johnson v. Iss, 114 Tenn. 114, 85 S.W. 79 (1905).

${ }^{10}$ Davis v. Pryor, 112 Fed. 274 (8th Cir. 1901) ; Carter v. Rinker, 174 Fed. 882 (C. C. Kau. 1909); Robinson v. Shockley, 266 S.W. 420 (Tex. Civ. App. 1924); Noice v. Brown, 38 N.J.I. 228 (1876); Leupert v. Shields, 14 Colo. App. 404, 60 Pac. 193 (1900); Siveyer v. Ollison, [1935] 2 K.B. 403. 
able, an action for breach of promise should lie for the reason. that there has been a breach of warranty of capacity to marry amounting to fraud or deceit. ${ }^{17}$ In Davis $v$. Pryor the court stated $:^{18}$

"We fully realize the just and well-settled rule of law which a man even though married, and for that reason incapacitated from executing a contract or promise of marriage to another, shall not escape liability for damages occasioned to a third party, if in point of fact, she entered into the contract with the ignorance of the fact, that he had a living wife."

The better view would seem to be that the promisor's incompetency to marry because of statute or court decree is no defense, if the promisee had no knowledge of the fact $;^{10}$ for the promisee has suffered damage through the fraud of the promisor and the latter should not be allowed to use his disability as a defense. In the cases where the enforceability turns on the construction of a statute like the one in the Holder case, most courts have interpreted them as mere restrictions upon marriage within the proscribed time and not a prohibition on the right to promise to marry. ${ }^{20}$

There is again a difference of judicial opinion as to the enforceability of the marriage contract even where the plaintiff knows that the defendant is incapable of contracting marriage. The group of cases which hold that the contract is unenforceable rely upon the principle that such promises (i.e., those made when plaintiff knows of defendant's inability) "tend to disrupt the stability of marriage." 21 The other group of cases allow an action on the promise even though the plaintiff knew that defendant was either married or incapacitated by statute or divorce decree. ${ }^{22}$

In Buelna $v$. Ryan, ${ }^{23}$ there was a legislative prohibition that " $a$ subsequent marriage is illegal and void when contracted by a di-

${ }^{17}$ Spiers v. Hunt, [1908] 1 K.B. 720; commented on in 24 I. T. REv. 183.

18112 Fed. 274, 277 (8th Cir. 1901).

10 The cases are collected in 47 A.L.R. 400.

20 Tierney v. Tierney, 86 Colo. 362, 281 Pac. 737 (1929); McVickar จ. MeVickax, 123 Misc., 644, 205 N.Y.Supp. 834 (Sup. Ct. 1924).

${ }^{21}$ Breach of Promise-Datidity of Promise Made Pending Decree Nisi by Party to Divorce Proceedings, 24 VA. L. REv. 77 (1938).

22 Buelna ซ. Ryan, 139 Cal. 630, 73 Pac. 466 (1903); Morgan v. Muench, 181 Iowa 719, 166 N.W. 819 (1916); Cooper v. Bower, 78 Kan. 156, 96 Pac. 59 (1908); Greenbach v. Stewart, 175 Okla. 500, 53 P.2d 542 (1936); seo also, Schodler, Marriage, Divorce, SeParation, aNd Domestio Reinitions (6th ed.), \$\$ 1287, 1929.

23 Buelna v. Ryan, supra note 22. 
vorced person within one year subsequent to the date of the divorce decree." Nevertheless the court said:

"After the divorce was granted the plaintiff was no longer a married woman and had the right to contract to marry and to marry outside the state. Under the section of the code, the plaintiff did not have the right to marry in this state until one year after the decree of divorce was entered; but she had the right to marry at a certain time; and she had the right before the time to agree to marry, provided the agreement was not to be consummated until the end of that time."

The leading English case on the subject which follows the view of the Buelna case, supra, is Fender $v$. Milday. ${ }^{24}$ There the plaintiff, a young woman, met the defendant, who was to her knowledge a married man. Sexual intercourse began to take place between them in 1932. In 1933 the defendant's wife obtained a decree nisi for the disolution of her marriage with him. The defendant had promised to marry the plaintiff when the decree became absolute but after the decree did become final, the defendant refused to marry the plaintiff. The case squarely presented the issue: whether a promise, made by one spouse after a decree nisi ${ }^{25}$ has been pronounced, to marry a third party after the decree has been made absolute, is void on the grounds of public policy. The court, in a three to two decision, decided in the negative, stating that courts are not lightly to interfere with freedom of contract, that since the consortium is broken by the decree nisi and the normal obligations and conditions of marriage have ceased at the issuance of such decree, that judicial experience has shown that reconciliation does not take place, for the bottom has dropped out of the marriage. ${ }^{26}$

The majority of the court was of the opinion that if reconciliation were likely it would have taken place before the institution of the suit; for petitions of divorce, the court said, are not "casual steps but a measure which requires deliberation and intention." The court rejected the argument that such promises tend toward 24 [1938] A.C. 1.

${ }_{25}$ " $[\mathrm{W}]$ here a decree nisi has . . . been obtained, although the marriage still exists legally, it is unlikely that a spouse will exercise the care and devotion hoped for between husband and wife." Contracts-Breach of PromiseEnforceability of Promise to Marry Made after Decree Nisi but Before Absolute Decree, 84 U. OF PA. L. REv. 1025, 1026.

${ }^{26}$ Fender v. Milday, [1938] A.C. 1, 21. 
immorality and suggested that such promises tend to establish moral relations by virtue of an early marriage.

A consideration which seems to be of great importance in the determination of whether a contract to marry should or should not be enforced is the probability that parties will reach a reconciliation if they are prevented by court or statutory decree from remarrying or contracting to remarry within a certain time. Statistical data as to the effectiveness of such a prohibition would be a valuable guide in deciding whether or not strict adherence to such prohibitions is warranted. If such data indicated that reconciliation is unlikely once a divorce suit has commenced, reasons for strict application of such restrictions would be lacking. Under circumstances which show that reconciliation is improbable the most desirable procedure for the courts to follow is to act in "accord with the present concept of the function of divorce to terminate a marriage which has in fact failed."27 This, of eourse, would alleviate the problem of the enforceability of contracts to marry entered into within a prohibited period. With the exception of the comment by Lord Atkin in the $F^{T}$ ender case, supra, to the effect that the number of decrees nisi which are not made absolute is only a minute fraction of those granted, there seems to be a dearth of such data. ${ }^{28}$

The dissenters in the Fender case did not look beyond the proposition that the promise was made while the promisor was still technically married, since the parties are considcred husband and wife until the decree nisi is made absolute. It was their contention that the contract tended to create an obstacle for reconciliation; that it was incompatible with the status of marriage. Lord Roche remarked that "the court cannot treat an expected or imminent divorce the same as divorce." ${ }^{\prime 29}$ A statement by Lord Russell, worth quoting for its literary quality, is : $:^{30}$

"The institution of marriage has long been on a slippery

slope. What was once a holy estate enduring for the joint

lives of the spouses is steadily assuming the charaeteristics of a contract for a tenancy at will."

To this Lord Killowin added that he did not wish to obstruct any person who desires to marry after divorce from taking that

${ }^{27}$ See, Divorce: Effect of Reconciliation on Right to Final Decree, 37

Garif. I. REv. 305 (1949).

${ }^{28}$ Fender $\vee$. Milday, [1938] A.C. 1 at 18.

${ }^{20} I d$, at 54 .

${ }^{30} I d$. at 34-35. 
step. He would "only compel a person already married to await with decency until he or she is no longer a married person before becoming the object of a fresh betrothal." 31

Reviews ${ }^{32}$ of the Fender case state that it is a departure from the rule that a breach of promise action cannot be maintained if the promisee knew of the promisor's marriage or of his statutory incompetency. The comments reveal that the apparent extension by the Fender case of breach of promise actions is clearly contrary to the modern American trend towards limiting all "heart balm" actions. ${ }^{33}$

Considering the cases reviewed and in spite of the legislative anti-heart balm trends, the most desirable attitude on the part of the court would seem to favor enforcing a promise to marry entercd into within a prohibited period but not to be consummated until the expiration of that period, provided that there are strong grounds warranting an action for breach of promise to marry. ${ }^{34}$ The contract should not be held invalid for the sole reason that it was entered into within the proseribed period. Two important considerations to be taken into account in determining the enforceability of such contracts are: (1) the probability of reconciliation of the divorced parties; and (2) the knowledge of the promisee of the promisor's inability. If it appears that reconciliation is unattainable, the promisor should be held to his promise if the promisee had no knowledge of the promisor's incapacity to marry or where the promisor fraudulently concealed his incompetency from the promisee to the damage of the latter.

It is difficult to require orthodox trial courts to handle these situations adequately when they are burdened with the interpretation of statutes which have been diversely construed and which frequently become inapplicable to novel situations. A drastic measure, but one that seems practical, would he to modify present marital legislation toward the end of establishing a group of judicial tribunals (perhaps special domestic relations courts) to dis-

32 Id. at 35.

39 Marriage, Contracts, and Public Policy, 54 HaRV. L. REv. 473, 476 (1941); Breach of Marriage Promise-Promise of Marriage by a Party to a Divorce Acticn After Entry of Decree Nisi Void as Against Public Policy, 49 HaRv. I. Rev. 648 (1936); Weyl, Breach of Promise-Liability for Promise Made Subsequent to Decree Nisi but Prior to Final Decree, 11 So. CaLIF. L. REv. 357 (1938). Also, see notes 21 and 25 supra, and 178 L. T. REv. 343 (1934).

"See note 21 supra.

- Vernier, op. cit. supra note 1, Vol. $1 \$ 6$. 
pose of these problems with whatever marriage counselling and adjudication that seems proper in the particular case. It is submitted that such considerations as these tribunals could offer, unhindered by legislation which crystalizes frequently into rules of thumb, will greatly facilitate the solution of problems involving marriage contracts and will better prevent the misearriages of justice which literal interpretations of statutes can often produce.

As an alternative solution, it is submitted that the enactment of two types of statutes would be helpful in coping with the problem raised by promises to marry. The first type would leave within the discretion of the trial court the power to determine the enforceability of sueh promises. The second type would impose criminal or contempt penalty by whieh the state would punish a person who made a promise to marry in violation of judicial decree or statutory enaetment. 